\title{
Employee Engagement through Corporate Social Responsibility: A Study of Executive and Managerial Level Employees of XYZ Company in Private Healthcare Services Sector
}

\author{
H. M. K. Nanayakkara, Y. M. S. W. V. Sangarandeniya \\ Department of Human Resource Management, University of Kelaniya, Kelaniya, Sri Lanka \\ Email: himehck95@gmail.com, sangarandeniya@kln.ac.lk
}

How to cite this paper: Nanayakkara, H. M. K., \& Sangarandeniya, Y. M. S. W. V. (2022). Employee Engagement through Corporate Social Responsibility: A Study of Executive and Managerial Level Employees of XYZ Company in Private Healthcare Services Sector. Open Journal of Business and Management, 10, 1-16.

https://doi.org/10.4236/ojbm.2022.101001

Received: October 29, 2021

Accepted: December 11, 2021

Published: December 14, 2021

Copyright () 2022 by author(s) and Scientific Research Publishing Inc. This work is licensed under the Creative Commons Attribution International License (CC BY 4.0).

http://creativecommons.org/licenses/by/4.0/

\begin{abstract}
Today, in this rapidly changing business world, organizations focus more than ever on corporate social responsibility as a strategy to achieve their overall business objectives and attain sustainability. Therefore, properly recognizing its impact on both company and its employees is crucial. This study aimed to identify the impact of perceived corporate social responsibility (CSR) on employee engagement. Further, it attempted to understand the relationship between CSR and employee engagement and assess the level of perceived corporate social responsibility and employee engagement among the selected sample. The final study sample consisted of Executive and Managerial level employees in a selected private hospital which engages in the healthcare services sector in Sri Lanka. The data were collected from 216 respondents using a self-administered questionnaire via both personal visits to the organization and internet-based methods. The study was a cross-sectional research study done in a non-contrived setting with minimal researcher interference. Descriptive statistics, correlation analysis, and simple regression analysis were mainly used for the analysis. The results revealed a significant positive relationship between the two variables. Further, it showed a significant positive impact of perceived CSR on employee engagement. These research findings provide compelling evidence of how CSR could work as an investment rather than a cost for the organizations. Thus, this study helps the organization focus its attention on improving the employee engagement ratio through CSR activities.
\end{abstract}

\section{Keywords}

Corporate Social Responsibility (CSR), Employee Engagement, Healthcare Services Sector 


\section{Introduction}

Organizations with the best and most engaged employees have greater success within the dynamic business environment. Engaged employees are more familiar with the company goals, objectives and more involved in business operations. Further, the well-engaged employees understand the business environment and collaborate with coworkers to improve job performance for the organization's benefit (Tsourvakas \& Yfantidou, 2018; Patro, 2013).

Organizations must understand the real drives of employee engagement to sustain it. The concept of engagement is still recent, and as such, there is a lack of understanding of what promotes employee engagement. Many scholars have identified different employee engagement drives such as autonomy, professional development, psychological safety, meaningful work, organizational reputation, etc. (Anitha, 2014; Chaudhary, 2017; Millar, 2012).

Therefore, organizations pressure themselves to be the best organization where employees prefer to work, resist leaving, and are highly engaged. Every person is more likely to occupy himself in a socially accepted and reputed company. On the other hand, consumers have started to look at the moral value of organizations. Furthermore, government and authorized parties have imposed rigid rules and regulations for organizations to be followed when carrying out their business operations. To answer all these rising questions, corporates have adopted Corporate Social Responsibility (CSR) initiatives. Chaudhary (2017) has mentioned that organizations gradually increase socially and environmentally responsible activities into their day-to-day management practices.

Within the last two decades, interest in CSR has increased among organizations. Though the CSR activities are conducted for the betterment of society, mainly as a voluntary act, the real corporate purpose behind that is questionable. However, it's important to ensure the benefits of organizational CSR should not be limited to the betterment of the society or environment but also for the whole stakeholder groups. Therefore, the benefits of CSR have been widely acknowledged by employees, consumers, Non-government Organizations (NGOs), governments, and future prospective employees (Kerr, Johnston, \& Beatson, 2008).

Organizations initiate CSR activities with the expectation of offering a helping hand to the community they operate. At the same time, organizations need to acquire an additional benefit for the sustainability of business operations based on their CSR investments (Galbreath, 2010). According to the discussion had with the management of the "XYZ Company," which operates in the private healthcare services sector, they are currently spending a considerable amount of money and effort on CSR activities. Further, they stated that even though most of the organizations in the private healthcare services sector in Sri Lanka are spending a lot of money on CSR activities, it is still questionable how and to what extent these CSR activities positively influence different stakeholder groups of these organizations. Therefore, it is important to conduct further studies to 
understand the benefits of CSR in different aspects. Thus, it is interesting to study the effect of CSR on employee behavior and attitudes taking the employees as a very important stakeholder group having long-term benefits towards the organization.

Supporting that notion, Towers (2008) has identified CSR as the third most important driver for enhancing overall employee engagement and retention among all age groups of employees. However, drives of engagement could depend on the economic and social status of the country as well as employees (Anitha, 2014). Moreover, Chaudhary (2017) stated that initiating a CSR program in a developed country could generate different results from initiating a CSR program in a developing country and has emphasized the importance of conducting studies on this area in other contexts. Further, it is rare to find similar studies done in Sri Lanka and also in the private healthcare services sector in Sri Lanka. Therefore, it is vital to investigate the Sri Lankan context of CSR and its effect on employee engagement in the Sri Lankan context. Thus, the authors examine whether CSR has a significant impact on employee engagement in the Sri Lankan context through this study.

\section{Objectives of the Study}

The prime objective of this study is to assess the impact of perceived CSR on employee engagement. Further, it attempts to assess the level of perceived CSR and the level of employee engagement. Moreover, it aimed to identify the relationship between perceived CSR and employee engagement.

\section{Significance of the Study}

Interestingly, few studies have been done on how CSR could affect employee engagement (Achivers, 2015; Albdour \& Altarawneh, 2012; Glavas, 2016; Tsourvakas \& Yfantidou, 2018). However, most of those studies have been carried out in developed countries (Carr, 2012; Mirvis, 2012; Slack, Corlett, \& Morris, 2014). Chaudhary (2017) stated significance and the type of the relationship between these two variables can be varied according to the specific cultural context and suggested testing it in different industries and cultures.

In addition to that, since no studies on this study area have been done in Sri Lanka and the private healthcare services sector in Sri Lanka, the present study will bridge the research gap on how CSR impacts employee engagement in the Sri Lankan context. Thus, at the same time, the study advances the existing body of knowledge beyond Western economies by exploring the strategic value of CSR in a developing country like Sri Lanka, which presents a unique cultural context to consider.

Further, these results are helpful for the relevant company in considering whether it is worthwhile for them to invest further in CSR. In addition to that, the study allows the organizations of the same industry to take corrective actions 
to increase their engagement level by using CSR initiatives.

Moreover, this study opens new avenues of research related to CSR and human resources practices. It will provide insights for future researchers who are interested in CSR and employee engagement. And the study will serve as a foundation study to carry out further research studies in this area in different industries.

\section{Literature Review}

\subsection{Employee Engagement}

The first well-established definition of employee engagement was "harnessing of organizations members' selves to their work roles; in engagement, people employ and express themselves physically, cognitively and emotionally during role performances" (Khan, 1990: p. 694). Khan identified the concept of employee engagement accompanied by the concepts of involvement, motivation, and satisfaction. Maslach, Schaufeli and Leiter (2001) have stated employee engagement as an employees' positive, motivational characteristic. However, employee engagement refers to "the individual's involvement and satisfaction and enthusiasm for work" (Harter, Schimdit, \& Hayes, 2002: p. 269).

Later on, Schaufeli, Bakker and Salanova (2006) identified the employee engagement dimensions as vigor, dedication, absorption. According to Fereirra and Oliveira (2014); and Schaufeli, Bakker and Salanova (2006), vigor is identified as the level of employees' willingness to work, the degree of effort, and energy that they are ready to invest in. Then, they have defined dedication as maintaining a high level of motivation, inspiration, substantial involvement in work, and experiencing a sense of significance. Finally, they have defined absorption as the degree to which employees happily and willingly immerse and completely concentrate on work where they feel that time passes quickly and feel difficulties when there is no work to perform.

Employee engagement could identify as one of the major contributors to face competitiveness (Aktar \& Pangil, 2017). Further, engaged employees are vital in achieving the competitive advantage because all other production factors could be initiated by the competitive organizations except the human resource (Ncube \& Jerie, 2012). Moreover, Parent and Lovelace (2018) mentioned that the engaged employees utilize their time and effort to build a positive environment and relationships within the workplace and multiply their productivity, effectiveness through those relationships to increase the outcome.

\subsection{Corporate Social Responsibility Units}

Bowen (1953, as cited in Turker, 2009) identified CSR as a set of responsibilities of a businessman to guide the business, make decisions, and conduct business operations in a favorable manner for society. Carroll (1979: p.500) examined the term CSR and claimed, "social responsibility of a business encompasses the eco- 
nomic, legal, ethical, and discretionary expectations that society has of organizations at a given point in time". CSR consists of making strategic business decisions accompanied by ethical, legal requirements and respect for the people, society, and environment (Albdour \& Altarawneh, 2012).

Bhaduri and Selarka (2016) stated organizations had recognized the importance of CSR not just from the societal perspective but also from the perspective of stakeholders and firms. The stakeholder approach expects the organizations to manage responsibilities to an extended network for all stakeholder interests (Jamali, 2008).

Turker (2009) mentioned that CSR could mean something to everyone, but that does not imply the same thing to everyone, emphasizing that different interest groups can have different expectations and perspectives. Bhaduri and Selarka (2016) argued that the organizations that operate by considering this theory expand their care net beyond the traditional interest groups of stakeholders as well as silent stakeholders such as local communities and the environment.

Initially, Turker (2009) introduced four main CSR dimensions to address the stakeholder perspective of CSR: "Primary Social" that consists of employees and clients, "Secondary Social" that includes the government, "Primary Non-social" that includes the natural environment and future generations, and finally, "Secondary Non-social" that includes NGOs.

According to Sun and Yu (2015), CSR initiatives positively impact organizational commitment and employee performance. Further, they mentioned that the way organizations treat their community proposes positive things to its' employees about how the organization perceives and values them. Therefore, employees may feel valued and respected by their organizations, and eventually, they feel more comfortable to occupy their best effort to work, leading to increased employee engagement (Apparo, 2016; Prutina, 2016; Sun \& Yu, 2015). If employees do not contain the idea of what is happening within the organization and how it will affect their lives, the employees of that organization will be disengaged (Chaudhary, 2017). Therefore many organizations maintain a separate sustainable team to engage with the bottom level of the organizations to identify and fulfill the CSR expectations (Epstein-Reeves, 2012).

\subsection{Corporate Social Responsibility and Employee Engagement}

The theories of engagement primarily focus on the relationship between employees and their organization, and the theories of CSR focus on the relationship between the organization and the community they operate. Interestingly, employees represent a considerable quota of that community. It means if an organization commits to providing social needs as a CSR activity, eventually, they improve the lives of their employees (Glavas, 2016). Higher levels of organizational CSR will generate positive employee relations and vice versa (Achivers, 2015). Further, Tariq (2015) has mentioned that organizational reputation for social responsibilities plays a vital role in employee engagement as well as employee 
retention.

According to Turker (2009), CSR has internal and external dimensions. Internal CSR such as training and development, fair and equal opportunities directly affect the employee stakeholder group. Crawford-Marks (2020) stated employees expect different things from their organization, and it could be their compensation or pay overall, job security, respectfulness and fairness for all employees, opportunities to apply their skills and abilities, recognition, autonomy and growth opportunities. Further, when considering the social exchange theory (SET), if employees perceive that their organization is focusing on fulfilling their socio-economic needs through business activities to ensure their well-being, then they may feel more responsible and, consequently show a higher level of engagement as their repayment (Aktar \& Pangil, 2017; Saks \& Rotman, 2006). By conducting a research study, Fereirra and Oliveira (2014) found a positive impact of CSR on employee engagement to some extent. Further, they have especially emphasized that employees exposed to internal CSR have shown a higher level of engagement when compared to the employees only exposed to external CSR.

Based on the study done on perceived organizational support (POS), Albdour and Altarawneh (2012) found that internal CSR practices directly affect employee attitude and behavior. According to Eisenberger, Malone and William (2016), POS works to increase employee dedication. Further, POS theory refers to employees' perception of what extent their organization values their work and concern for their well-being, as well as takes actions to ensure employee wellbeing (Eisenberger, Malone, \& William 2016). Based on SET and POS theories, employees who perceive that their organization is being supportive and caring towards their CSR requirements, those employees' are more psychologically and emotionally bound and attached to their organization (Khaliq Alvi, Abbasi, \& Sattar, 2014). Glavas (2016) stated that CSR could identify as an antecedent of POS, and there is a significant positive relationship between CSR and POS.

Some scholars have emerged the relationship between CSR and employee engagement by using social identity theory (SIT), which refers to ones' perception of their organization where he or she describe their identity in terms of the organizations that they belong to (Mousiolisa \& Bourlet, 2015). Furthermore, based on SIT, Farooq, Payaud, Merunka and Valette-Florence (2013) have suggested, firm's CSR activities create a direct impact on organizational reputation and do send a hint to the external parties such as future generations, government, society, and especially to prospective employees regarding the attractiveness of the employer. Moreover, Tyler argued (as cited in Farooq, Payaud, Merunka, \& Valette-Florence, 2013) that employees use their organization's reputation, CSR prestige, and social standing to assess their self-worth.

After considering all the above theories and empirical evidence on CSR and employee engagement, the researchers developed the following conceptual framework for the study (Figure 1). 


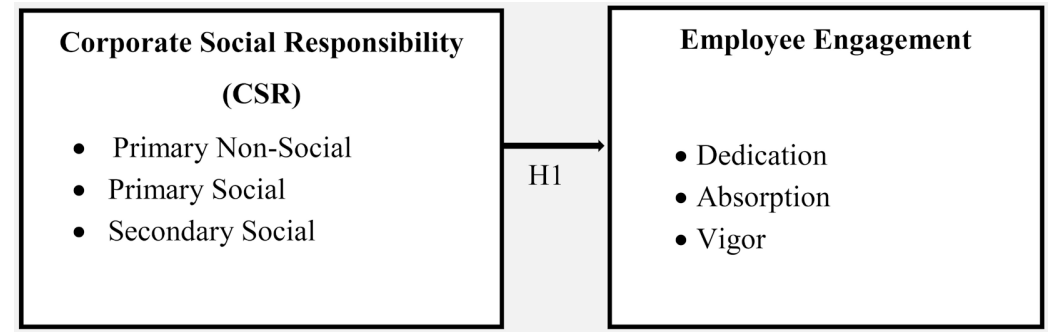

Figure 1. Conceptual framework.

When considering all the relevant definitions, it shows Schaufeli, Salnova, Gonzalvez-Roma and Bakker (2002) have broadened the concept of employee engagement and its dimensions. Therefore, the operational definition for employee engagement is a positive state of employees physical and psychological attachment or the involvement with their organization characterized by energy, motivation and the extent of their willingness to go for an extra mile to perform their assigned tasks (Schaufeli, Salnova, Gonzalvez-Roma, \& Bakker, 2002). Accordingly, current researchers use three main dimensions of employee engagement: vigor, dedication, and absorption.

The current researchers consider the stakeholders' approach in addressing the concept of CSR. The operational definition of CSR is the set of actions that are taken by the organizations to acquire a social and environmental advancement, especially for stakeholders' concerns and finding a balance between organizations' economic needs, stakeholder expectations, and legal boundaries focusing on working above and beyond the economic goals of the organization (Carroll, 2001). As Turker (2009) claimed, stakeholders affected by the organizational CSR activities are the employees, customers, prospective employees, natural environment, future generations, government, and NGOs.

Furthermore, the researchers formulated the following hypothesis for the study based on the same theoretical and empirical background.

\section{$\mathrm{H1}$ : There is a significant impact of perceived CSR on employee engage-} ment.

Assuming that there can be an impact of CSR activities of the organization on employee engagement, the researchers developed the above hypotheses tentatively and to be tested.

H0: There is no significant impact of perceived CSR on employee engagement.

\section{Methodology}

\subsection{Sample and Procedure}

This study could identify as a quantitative-explanatory study, and the researchers used the deductive research approach. The researchers have selected a compelling key player in the private healthcare services sector in Sri Lanka as the research context. Based on the ethical consideration hypothetical name was used 
by the researchers as XYZ Company. The current study is a cross-sectional study since data were collected at a particular point in time, and it did not repeat. A self-administered questionnaire was used to collect data for the study; therefore, the researchers' interference was minimal for this study.

There were 278 executive and managerial level employees in the selected private hospital engaged in the healthcare services sector. The whole population of 278 executive and managerial level employees was considered for the sample of the current study, and only 216 among them were responded and returned the fully completed questionnaire [Response Rate $=77 \%$ ]. Collected data were analyzed using descriptive statistics, correlation analysis, and regression analysis.

\subsection{Measurement Scales}

The survey questionnaire consists of three sections to measure demographic factors, employee engagement, and CSR. The researchers used well-established measurement scales that have been used by previous researchers to measure employee engagement and CSR in the current study. Section A includes five demographic factors: gender, age group, highest education qualification, work experience within the existing organization, and monthly income.

The Utrecht Work Engagement Scale (UWES) developed by Schaufeli, Salnova, Gonzalvez-Roma and Bakker (2002) was used to measure employee engagement that consisted of 17 items. It measures employee engagement under three dimensions: vigor (6 items), dedication (5 items), and absorption (6 items). Further, Tucker's 17 item CSR scale is the only scale available in the literature that has adopted the stakeholders' approach, which is appropriate to measure the CSR perceptions of employees (Chaudhary, 2017). It is the widely used and wellestablished scale (Farooq, Payaud, Merunka, \& Valette-Florence, 2013) to measure the CSR perception of employees. Since the current research study also expects to measure the employees' CSR perception, the researchers decided to use Tucker's CSR scale to measure the perceived CSR. Accordingly, the employee perceived CSR was measured under four dimensions: primary-non-social (7 items), primary-social (7 items), secondary-social (2 items), secondary non-social (1 item).

\section{Data analyses and Presentation}

\subsection{Demographic Information}

Table 1 presents the level of employee engagement and CSR within the selected sample respondents.

\subsection{Preliminary Analysis}

Reliability was examined with Cronbach's Alpha test. Accordingly, all values of reliability are greater than .7 , which indicates the high internal reliability of the measures. The results of the Cronbach's Alpha test are given in Table 2, which suggests that the reliability of each instrument is satisfactory 
Table 1. Frequency and the percentages of demographic variables.

\begin{tabular}{|c|c|c|c|}
\hline \multirow{2}{*}{ Category } & \multicolumn{3}{|c|}{ Demographic Variables } \\
\hline & Components & Frequency & Percentage \\
\hline \multirow{2}{*}{ Gender } & Male & 167 & $77.3 \%$ \\
\hline & Female & 49 & $22.7 \%$ \\
\hline \multirow{5}{*}{ Age } & Less than 25 years & 27 & $12.5 \%$ \\
\hline & 25 - 35 years & 91 & $42.1 \%$ \\
\hline & $35-45$ years & 71 & $32.9 \%$ \\
\hline & 45 - 55 years & 27 & $12.5 \%$ \\
\hline & More than 55 years & 0 & $.0 \%$ \\
\hline \multirow{5}{*}{$\begin{array}{l}\text { Work Experience } \\
\text { within } \\
\text { the current organi- } \\
\text { zation }\end{array}$} & Less than 5 years & 52 & $24.1 \%$ \\
\hline & Between 5 - 10 years & 91 & $42.1 \%$ \\
\hline & Between 15 - 20 years & 49 & $22.7 \%$ \\
\hline & Between 20 - 25 years & 19 & $8.8 \%$ \\
\hline & More than 25 years & 5 & $2.3 \%$ \\
\hline \multirow{5}{*}{$\begin{array}{c}\text { Education Qualifica- } \\
\text { tion }\end{array}$} & G.C.E. Advanced Level & 0 & $.0 \%$ \\
\hline & Diploma & 72 & $33.3 \%$ \\
\hline & Bachelors' Degree & 68 & $31.5 \%$ \\
\hline & Masters' Degree & 68 & $31.5 \%$ \\
\hline & Postgraduate Degree & 8 & $3.7 \%$ \\
\hline \multirow{5}{*}{ Monthly Income } & Less than Rs. 50,000 & 50 & $23.1 \%$ \\
\hline & Rs. 50,000 - Rs. 75,000 & 60 & $27.8 \%$ \\
\hline & Rs. 75,000 - Rs. 100,000 & 46 & $21.3 \%$ \\
\hline & Rs. 100,000 - Rs. 125,000 & 38 & $17.6 \%$ \\
\hline & More than Rs. 125,000 & 22 & $10.2 \%$ \\
\hline
\end{tabular}

Table 2. Results of the Cronbach's alpha test.

\begin{tabular}{ccc}
\hline \multicolumn{3}{c}{ Cronbach's Alpha Test } \\
\hline Measures & Cronbach's Alpha & N of Items \\
\hline Employee Engagement & .904 & 17 \\
CSR & .878 & 17
\end{tabular}

Sampling adequacy and sphericity were tested with the Kaiser-Meyer-Olkin (KMO) test and the Bartlett's test, respectively. According to the results of the $\mathrm{KMO}$, both instruments' KMO values [Employee Engagement $=.800$, CSR $=.733$ ] are greater than .7, and the significant values' of both instruments are less than .05 . Therefore, these test results ensure sample adequacy. Further, sphericity was ensured since all the variables' sig values were .000, which was less than .05 . Further, according to validity statistics, the cumulative percentage of the Extrac- 
tion Sums of Squared Loadings (ESSL Cum\%) of SCR [62.234\%] and employee engagement [59.422\%] are greater than 50\%, and the all item factor loading values are above the threshold value of .5 for all the items. Thus, these results statistically ensured the construct validity of the measurement scale. Moreover, the content validity of the instrument was ensured by employing the standard questionnaires to measure both variables of the study.

The normality of the data was tested with the statistics of Skewness and Kurtosis. It can be considered that the data are approximately normally distributed when both the Skewness and Kurtosis values are in between +2 and -2 (Garson, 2012). Thus, normality of the data was ensured with the Skewness [CSR = -1.547, Employee Engagement $=-.613$ ] and Kurtosis $[$ CSR $=2.304$, Employee Engagement $=-.66]$ staistics of the data distribution for both variables. Further, the scatter plot diagram was drawn to examine linearity between variables, and scatter plots were approximately linear according to the visual inspection.

Moreover, the ANOVA test for linearity between variables was performed, and linearity was ensured with the Sig. value of the linearity coefficient $[p=.000$, $p<.05]$ and Sig. value of the deviation from linearity coefficient $[p=.092, p>.05]$. Since the above results ensured the linear relationship between variables, Pearson Correlations analysis was performed to test the direction and the strength of the relationship between CSR and employee engagement.

\subsection{Descriptive Statistics of CSR and Employee Engagement}

The frequency distribution analysis was made separately for the independent variable of CSR and the dependent variable of employee engagement

As illustrated in Table 3, the mean value of employee engagement is 3.9261, and the mean value of CSR is 4.1300. Therefore, both the level of employee engagement and the CSR of the respondents are at a "High" level.

\subsection{Correlation Analysis between CSR and Employee Engagement}

Table 4 illustrates that the correlation coefficient is .721, significant at $99 \%$ [ $p$ $=.000]$ confidence level. Therefore, these results show that there is a significant moderate relationship between perceived CSR and employee engagement.

\subsection{Hypotheses Testing}

The simple regression analysis was performed to test the impact of CSR on employee engagement of executive and managerial level employees working at XYZ Company.

As per the results of the regression analysis shown in Table 5, R2 is .520, and it indicates CSR has a 52\% impact on employee engagement of executive and managerial level employees in XYZ Company. In other words, 52\% of the variation in employee engagement is explained by CSR. Further, the statistics in the ANOVA table show that the overall regression model statistically significantly predicts the outcome variable $[\mathrm{F}=69.536, p=.000]$. 
Table 3. Descriptive statistics of CSR and employee engagement.

\begin{tabular}{cc}
\hline Variable & Mean value \\
\hline Employee Engagement & 3.9261 \\
CSR & 4.1300 \\
\hline
\end{tabular}

Table 4. Correlation analysis between CSR and employee engagement.

\begin{tabular}{cccc}
\hline & & $\begin{array}{c}\text { Corporate Social } \\
\text { Responsibility }\end{array}$ & $\begin{array}{c}\text { Employee } \\
\text { Engagement }\end{array}$ \\
\hline CSR & Pearson Correlation & 1 & $.721^{* *}$ \\
Sig. (2-tailed) & $\mathrm{N}$ & 216 & .000 \\
Employee & Pearson Correlation & $.721^{* *}$ & 216 \\
Engagement & Sig. (2-tailed) & .000 & 1 \\
& $\mathrm{~N}$ & 216 & 216 \\
\hline
\end{tabular}

**. Correlation is significant at the .01 level (2-tailed).

Table 5. Correlation analysis between CSR and employee engagement.

\begin{tabular}{ccccc}
\hline Model & $\mathrm{R}$ & R Square & Adjusted R Square & Std. Error of the Estimate \\
\hline 1 & $.721 \mathrm{a}$ & .520 & .511 & .36087 \\
\hline
\end{tabular}

Moreover, according to the coefficient table, the $\mathrm{b}$ value is $.806[p=.000]$. The $b$ value predicts the impact of the independent variable on dependent variables. Thus, it indicates that employee engagement has a positive effect of .806 for one unit of change in CSR. Accordingly to the above results, the $\mathrm{H} 1$ hypothesis: there is a significant impact of CSR on employee engagement was accepted. Thus, it indicates that CSR has a significant positive effect on employee engagement.

\section{Key Findings and Conclusion}

The results of the correlation analysis indicated a significantly moderate positive relationship between perceived CSR and employee engagement $[\mathrm{R}=.721, p$ $=.000]$.

The results of the regression analysis $\left[\mathrm{R}^{2}=.520\right]$ indicate that $52 \%$ of employee engagement explains through CSR perception of executive and managerial level employees in XYZ Company. Further, these results, along with the $\mathrm{b}$ value $[\mathrm{b}=.806, p=.000]$, illustrate a significant positive impact of perceived CSR on employee engagement. These findings align with the findings of previous researchers such as Chaudhary (2017), Fereirra and Oliveira (2014), and Slack, Corlett and Morris (2014) who have done similar studies in different contexts. Further, the results of the study emphasize that organizational CSR initiatives could make a difference in employee engagement.

According to the analysis of descriptive statistics, it was found that both the 
level of employee engagement [ $\mathrm{m}=3.9261]$ and the perceived CSR $[\mathrm{m}=4.1300]$ of the respondents are at a "High" level. Apart from that, according to these results, $87.7 \%$ of employees indicated a higher engagement level. Therefore, most of the employees showed a higher level of employee engagement, and there were no employees who showed a lower engagement level. Consequently, it indicates that most employees are psychologically and physically involved with their organization. Moreover, $93 \%$ of employees of that organization perceive that their organization is highly engaged in CSR activities.

In conclusion, the employees tend to be highly engaged when they feel that organizations care about their employees, customers, future generations, the natural environment, and the government. Therefore, the organizations could increase their level of employee engagement by implementing sound CSR practices.

\section{Implications}

Current research findings provide compelling evidence of how CSR could work as an investment rather than a cost function. Thus, this study helps the organization focus its attention on improving the employee engagement ratio through CSR initiatives.

This research study bridges the gap in existing academic literature. It has a critical dearth of studies regarding how CSR initiatives could affect employee engagement when considering the stakeholder approach. Moreover, since most studies have proceeded within Western European countries regarding the above concept (Tsourvakas \& Yfantidou, 2018), this research study will expand the body of knowledge about CSR and employee engagement in developing eastern countries such as Sri Lanka.

\section{Direction for Future Studies}

Since this research study considered only one company that engages in the private healthcare services sector, generalization of the findings of this research to every organization within the Sri Lankan context was limited. The authors encourage future researchers to test the proposed research model with different organizations, industries, and cultural contexts to improve the generalizability of the study results. Further, it would be useful to look for the changing nature of the relationship between the variables over time due to fluctuating business environment and the performance of the organization. Thus, longitudinal studies are desired in the area to assess and establish the direction of the relationship and test whether reciprocal relationships exist.

Future studies might consider using qualitative techniques to get a broader understanding of the relationship between CSR and employee engagement. Hopefully, this study would raise the levels of interest among scholars to conduct more studies regarding the impact of CSR initiatives on employee engagement.

Further, the findings of the current study provide several ideas for future in- 
vestigations. Different employees may respond differently to CSR efforts of the organization; therefore, it is vital to examine the moderating factors such as gender, age, marital status, which could affect the nature of the relationship. In addition to that, employee personality and individual characteristics may influence the strength of the relationship between two variables. Further, Kim, Woo, Uysal and Kwon (2018) have found that philanthropic and economic CSR positively affects the quality of work life. Furthermore, Abeykoon and Sangarandeniya (2020) have found that there is a strong positive relationship between well-being and employee job engagement. Therefore, future studies could be undertaken to test the mediating effect of employee well-being on the relationship between CSR and employee engagement.

\section{Conflicts of Interest}

The authors declare no conflicts of interest regarding the publication of this paper.

\section{References}

Abeykoon, S. M., \& Sangarandeniya, Y. M. S. W. V. (2020). Impact of Employee Well-Being on Employee Job Engagement: A Study of Managerial Level Employees in Civi-Tech Engineering and Construction (Pvt) Ltd. In 7th HRM Student Research Symposium, 2020 (p. 25). Department of Human Resource Management, Faculty of Commerce and Management Studies, University of Kelaniya.

Achivers (2015). The Importance of Corporate Social Responsibility Programs for Employee Engagement.

https://www.achievers.com/blog/2015/06/the-importance-of-corporate-social-responsi bility/

Aktar, A., \& Pangil, F. (2017). The Relationship between Employee Engagement HRM Practices and Perceived Organizational Support: Evidence from Banking Employees. International Journal of Human Resource Studies, 7, 2-22.

Albdour, A. A., \& Altarawneh, I. I. (2012). Corporate Social Responsibility and Employee Engagement in Jordan. International Journal of Business and Management, 16, 90-105.

Anitha, J. (2014). Determinants of Employee Engagement and Their Impact on Employee Performance. International Journal of Productivity and Performance Management, 63, 308-323. https://doi.org/10.1108/IJPPM-01-2013-0008

Apparo (2016). 3 Major Benefits of Corporate Social Responsibility. Charlotte Business Journal.

https://www.bizjournals.com/charlotte/news/2017/12/06/3-major-benefits-of-corporat e-social.html

Bhaduri, S. N., \& Selarka, E. (2016). Corporate Social Responsibility around the World: An Overview of Theoretical Framework and Evaluation. In S. O. Idowu, \& R. Schmidpeter, Corporate Governance and Corporate Social Responsibility of Indian Companies (pp. 11-32). Springer. https://doi.org/10.1007/978-981-10-0925-9 2

https://www.springer.com/series/11565

Carr, G. (2012). Employee Engagement Is the Key to CSR Participation. CSR Matters. http://csrmatters.net/2018/04/employee-engagement-is-the-key-to-csr-participation/

Carroll, A. B. (1979). A Three-Dimensional Conceptual Model of Corporate Performance. 
The Academy of Management Review, 4, 497-505. https://doi.org/10.2307/257850

Carroll, A. B. (2001). The Pyramid of Corporate Social Responsibility: Toward the Moral Management of Organizational Stakeholders. Business Horizon, 34, 39-48. https://doi.org/10.1016/0007-6813(91)90005-G

Chaudhary, R. (2017). Corporate Social Responsibility and Employee Engagement: Can CSR Help in Redressing the Engagement Gap? Social Responsibility Journal, 13, 323338. https://doi.org/10.1108/SRJ-07-2016-0115

Crawford-Marks, R. (2020, July 22). Employee Expectations in Modern Business. https://blog.bonus.ly/employee-expectations-in-modern-business/

Eisenberger, R., Malone, G. P., \& Presson, W. D. (2016). Optimizing Perceived Organizational Support to Enhance Employee Engagement. Society for Human Resource Management and Society for Industrial and Organizational Psychology, 2, 3-22.

Epstein-Reeves, J. (2012). Six Reasons Companies Should Embrace CSR. Forbes. https://www.forbes.com/sites/csr/2012/02/21/six-reasons-companies-should-embracecsr/\#7170bf3c3495

Farooq, O., Payaud, M., Merunka, D., \& Valette-Florence, P. (2013). The Impact of Corporate Social Responsibility on Organizational Commitment: Exploring Multiple Mediation Mechanisms. Journal of Business Ethics, 125, 563-580.

https://doi.org/10.1007/s10551-013-1928-3

Fereirra, P., \& Oliveira, E. R. (2014). Does Corporate Social Responsibility Impact Employee Engagement? Journal of Workplace Learning, 26, 232-248.

https://doi.org/10.1108/JWL-09-2013-0070

Galbreath, J. (2010). Drivers of Corporate Social Responsibility: The Role of Formal Strategic Planning and Firm Culture. British Journal of Management, 21, 511-525. https://doi.org/10.1111/j.1467-8551.2009.00633.x

Garson, G. D. (2012). Testing Statistical Assumptions. Statistical Associates Publishing.

Glavas, A. (2016). Corporate Social Responsibility and Employee Engagement: Enabling Employees to Employ More of Their Whole Selves at Work. Frontiers in Psychology, 7, Article No. 796.

https://www.ncbi.nlm.nih.gov/pmc/articles/PMC4886691/\#idm140345883101312title https://doi.org/10.3389/fpsyg.2016.00796

Harter, J. K., Schimdit, F. L., \& Hayes, T. L. (2002). Business-Unit-Level Relationship between Employee Satisfaction, Employee Engagement, and Business Outcomes: A Meta-Analysis. Journal of Applied Psychology, 87, 268-279.

https://doi.org/10.1037/0021-9010.87.2.268

Jamali, D. (2008). A Stakeholder Approach to Corporate Social Responsibility: A Fresh Perspective into Theory and Practice. Journal of Business Ethics, 82, 213-231. https://doi.org/10.1007/s10551-007-9572-4

Kerr, G., Johnston, K., \& Beatson, A. (2008). A Framework of Corporate Social Responsibility for Advertising Accountability: The Case of Australian Government Advertising Campaign. Journal of Marketing Communications, 14, 155-169. https://doi.org/10.1080/13527260701858539

Khaliq Alvi, A., Abbasi, A. S., \& Sattar, R. (2014). Relationship of Perceived Organizational Support and Employee Engagement. Journal of Science International, 26, 951954.

Khan, W. (1990). Psychological Conditions of Personal Engagement and Disengagement at Work. The Academy of Management Journal, 33, 692-724. 
Kim, H. L., Woo, E., Uysal, M., \& Kwon, N. (2018). The Effects of Corporate Social Responsibility (CSR) on Employee Well-Being in the Hospitality Industry. International Journal of Contemporary Hospitality Management, 30, 1584-1600. https://doi.org/10.1108/IJCHM-03-2016-0166

Maslach, C., Schaufeli, W. B., \& Leiter, M. P. (2001). Job Burnout. Annual Review of Psychology, 52, 397-422. https://doi.org/10.1146/annurev.psych.52.1.397

Millar, G. (2012). Employee Engagement-A New Paradigm. Human Resource Management International Digest, 20, 3-5. https://doi.org/10.1108/09670731211208085

Mirvis, P. H. (2012, April 9). Employee Engagement and Corporate Social Responsibility. In W. J. Rothwell, J. Lindholm, K. K. Yarrish, \& A. G. Zaballero (Eds.), The Encyclopedia of Human Resource Management (pp. 274-286). John Wiley \& Sons. https://doi.org/10.1002/9781118364710.ch22

Mousiolisa, D. T., \& Bourlet, K. (2015). The Corporate Identity through the CSR's Paths. Procedia-Social and Behavioral Sciences, 175, 511-514. https://doi.org/10.1016/j.sbspro.2015.01.1230

Ncube, F., \& Jerie, S. (2012). Leveraging Employee Engagement for Competitive Advantage in the Hospitality Industry: A Comparative Study of Hotels A and B in Zimbabwe. Journal of Emerging Trends in Economics and Management Sciences, 3, 380-388.

Parent, J. D., \& Lovelace, K. J. (2018). Employee Engagement, Positive Organizational Culture, and Individual Adaptability. On the Horizon, 26, 206-214. https://doi.org/10.1108/OTH-01-2018-0003

Patro, C. S. (2013). The Impact of Employee Engagement on Organization's Productivity. In 2nd International Conference on Managing Human Resources at the Workplace (pp. 1-9). SDMIMD.

Prutina, Ž. (2016). The Effect of Corporate Social Responsibility on Organizational Commitment. Management, 21, 227-248.

Saks, A. M., \& Rotman, J. L. (2006). Antecedents and Consequences of Employee Engagement. Journal of Managerial Psychology, 21, 600-619.

https://doi.org/10.1108/02683940610690169

Schaufeli, W. B., Bakker, A. B., \& Salanova, M. (2006). The Measurement of Work Engagement with a Short Questionnaire: A Cross-National Study. Journal of Educational and Psychological Measurement, 66, 701-716.

https://doi.org/10.1177/0013164405282471

Schaufeli, W. B., Salnova, M., Gonzalvez-Roma, V., \& Bakker, A. B. (2002). The Measurement of Engagement and Burnout: A Confirmatory Factor Analytic Approach. Journal of Happiness Studies, 3, 71-92. https://doi.org/10.1023/A:1015630930326

Slack, R. E., Corlett, S., \& Morris, R. (2014). Exploring Employee Engagement with Corporate Social Responsibility: A Social Exchange Perspective on Organizational Perception. Journal of Business Ethics, 127, 537-548.

https://doi.org/10.1007/s10551-014-2057-3

Sun, L., \& Yu, R. (2015). The Impact of Corporate Social Responsibility on Employee Performance and Cost. Review of Accounting and Finance, 14, 262-284. https://doi.org/10.1108/RAF-03-2014-0025

Tariq, H. M. (2015). Effect of CSR on Employee Engagement. Indian Journal of Science and Technology, 8, 1-6. https://doi.org/10.17485/ijst/2015/v8iS4/64700

Towers, P. (2008). Global Workforce Study: Employee Engagement. Octainner.

Tsourvakas, G., \& Yfantidou, L. (2018). Corporate Social Responsibility Influences Em- 
ployee Engagement. Social Responsibility Journal, 14, 123-137.

https://doi.org/10.1108/SRJ-09-2016-0153

Turker, D. (2009). Measuring Corporate Social Responsibility: A Scale Development Study. Journal of Business Ethics, 85, 411-427. https://doi.org/10.1007/s10551-008-9780-6 